\title{
Alicja Grześkowiak
}

Uniwersytet Ekonomiczny we Wrocławiu

\section{CECHY PRACY A SKLONNOŚĆ POLAKÓW W WIEKU 50+ DO REZYGNACJI Z AKTYWNOŚCI ZAWODOWEJ*}

\begin{abstract}
Streszczenie: W pracy podjęto tematykę relacji pomiędzy oceną własności wykonywanej pracy a skłonnością Polaków w wieku 50+ do dezaktywizacji zawodowej. Na podstawie wyników dwóch sondaży przeprowadzonych w ramach projektu SHARE zweryfikowano hipotezę o istnieniu związku pomiędzy oceną cech pracy a chęcią jak najszybszego przejścia na emeryturę. Stosując mierniki adekwatne dla zmiennych niemetrycznych, przeprowadzono pomiar kierunku i siły związku pomiędzy opiniami wyrażonymi przez respondentów. Analizę wzbogacono wizualizacją czteropolowych tabel kontyngencji. Przeprowadzone badanie wskazuje, że istnieje statystycznie istotny związek pomiędzy percepcją niektórych cech pracy a skłonnością Polaków do rezygnacji z dotychczasowego zatrudnienia, jednakże siła tego związku jest raczej słaba. Otrzymany rezultat sugeruje, że zasadnicze uwarunkowania chęci przejścia na emeryturę mają prawdopodobnie inny charakter.
\end{abstract}

Słowa kluczowe: cechy pracy, dezaktywizacja zawodowa, osoby $50+$.

DOI: 10.15611/eis.2014.1.04

\section{Wstęp}

Obserwowane w większości krajów europejskich starzenie się społeczeństw niesie wiele różnorakich konsekwencji. Przemiany demograficzne wymuszają między innymi konieczność wprowadzania zmian w systemach zabezpieczeń społecznych. W Polsce, gdzie tempo starzenia się ludności jest bardzo szybkie, podwyższono docelowo wiek emerytalny do 67 lat, dając jednocześnie możliwość pobierania częściowej emerytury osobom dysponującym odpowiednim stażem pracy i stosownym wiekiem (62 lata kobiety oraz 65 lat mężczyźni) ${ }^{1}$. Wydłużenie okresu pracy powinno spowodować większe wykorzystanie potencjału siły roboczej ze starszych grup wieku. Według danych

\footnotetext{
* Praca naukowa sfinansowana ze środków Narodowego Centrum Nauki w ramach projektu badawczego 2012/05/B/HS4/02499.

${ }^{1}$ Ustawa z dnia 11 maja 2012 r. o zmianie ustawy o emeryturach i rentach z Funduszu Ubezpieczeń Społecznych oraz niektórych innych ustaw, DzU 2012, nr 0, poz. 637.
} 
Eurostatu, Polska zajmuje wśród krajów UE dwudzieste trzecie miejsce pod względem wskaźnika zatrudnienia osób w wieku 50-64 lata (49,4\% w 2012 r., podczas gdy średnia unijna wyniosła $58,4 \%)^{2}$. Z kolei prace analityczne wykonywane przez OECD pozwalają prześledzić kształtowanie się tzw. efektywnego wieku emerytalnego obliczanego jako średnia ważona wycofań (netto) z rynku pracy osób w różnym wieku w pięcioletnim okresie ${ }^{3}$. Kształtowanie się tego wskaźnika w Polsce przedstawia rys. 1 .

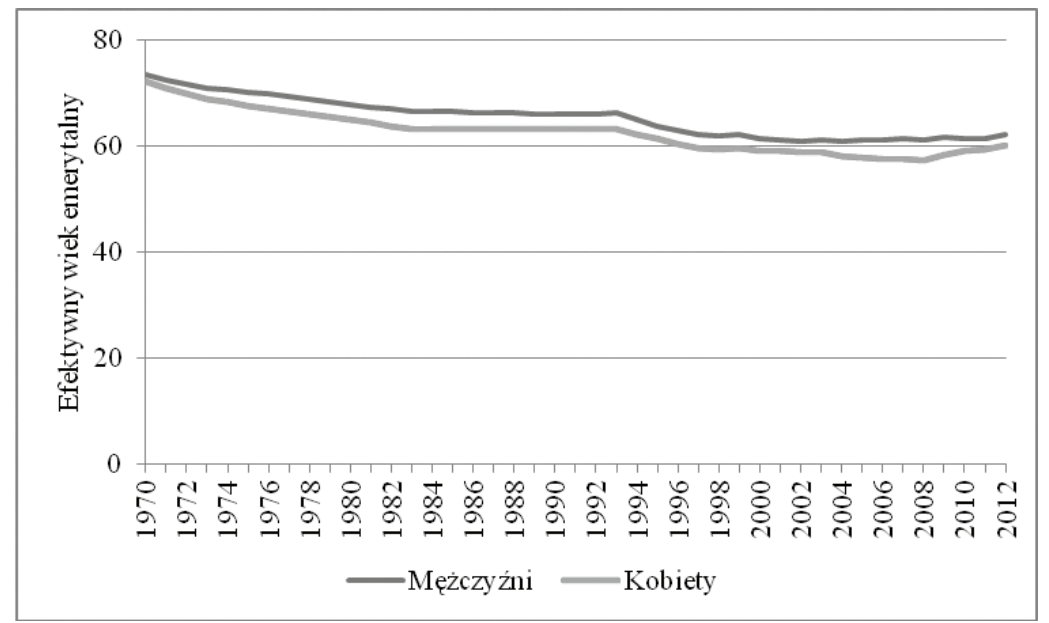

Rys. 1. Przeciętny efektywny wiek emerytalny kobiet i mężczyzn w Polsce (pięcioletnia średnia ruchoma, na skali podano ostatni rok wliczany do średniej)

Źródło: opracowanie na podstawie danych OECD.

Począwszy od lat siedemdziesiątych ubiegłego wieku, zauważyć można regularny spadek efektywnego wieku emerytalnego w Polsce. W przypadku mężczyzn był on niższy od obowiązującego ustawowo ${ }^{4}$, począwszy od wartości obliczonej na podstawie danych z lat 1990-1995. Dla kobiet spadek średniej poniżej oficjalnego progu nastąpił od okresu 1992-1997. Wskaźnik odnoszący się do mężczyzn przyjął najniższą wartość (61 lat) za lata 1999-2004, natomiast obliczony dla kobiet był najmniejszy (57,5 roku) za lata 2003-2008. Systematyczny nieznaczny wzrost, i to jedynie dla kobiet, miał miejsce dopiero dla ostatnich trzech pięcioletnich zestawów danych.

Obecna sytuacja w znacznej mierze wynika z polityki przyspieszonej dezaktywizacji osób starszych, która wystąpiła w okresie transformacji systemowej ${ }^{6}$, a wynikała

${ }^{2} \mathrm{http}: / /$ epp.eurostat.ec.europa.eu, Ifsa_ergaed [dostęp 2014-01-07].

${ }^{3} \mathrm{http}$ ://www.oecd.org/els/emp/Summary_1970+values.xls [dostęp 2014-01-07].

${ }^{4} 65$ lat według przepisów prawnych obowiązujących do $2012 \mathrm{r}$.

${ }^{5} 60$ lat według przepisów prawnych obowiązujących do $2012 \mathrm{r}$.

${ }^{6}$ M. Kabaj, Aktywność zawodowa i zatrudnienie ludzi starszych, [w:] Polska w obliczu starzenia się społeczeństwa. PAN, Komitet Prognoz „Polska 2000 Plus”, Warszawa 2008, s. 110. 
z różnych przesłanek: dążenia do ograniczania skali wzrostu bezrobocia, tworzenia warunków do obniżania zatrudnienia w przedsiębiorstwach i rotacji pracowników w sensie wymiany pokoleniowej, lansowania poglądu, że rezygnacja z tej części zasobów pracy ułatwi prywatyzację i restrukturyzację ${ }^{7}$. Zmieniające się warunki demograficzne zmuszają jednak do podjęcia działań na rzecz zwiększania zatrudnienia w starszych grupach wieku. Na decyzje o pozostaniu na rynku pracy bądź powrocie do aktywności zawodowej ma wpływ wiele uwarunkowań, do których można zaliczyć między innymi: stan zdrowia, sytuację rodzinną, zasobność materialną, wykształcenie, rozmiar popytu na pracę, rozwiązania prawne w zakresie ubezpieczeń społecznych i opieki socjalnej, stosowane instrumenty rynku pracy oraz postawy wobec pracy ${ }^{8}$. Wymienione czynniki mają charakter ekonomiczny, socjalno-bytowy oraz psychospołeczny9.

Niniejszy artykuł podejmuje próbę oceny znaczenia jednej z grup czynników związanych z percepcją warunków pracy w kontekście skłonności osób starszych do przechodzenia na emeryturę. Zasadniczym celem opracowania jest weryfikacja hipotezy, że istnieje związek pomiędzy różnymi przeświadczeniami na temat cech wykonywanej pracy a tendencją do dezaktywizacji zawodowej. Głównemu celowi podporządkowano cele szczegółowe: po pierwsze - statystyczny pomiar siły związku pomiędzy analizowanymi zjawiskami, po drugie - ocenę możliwości przewidywania decyzji o przejściu na emeryturę w zależności od przekonań dotyczących właściwości pracy zawodowej. Artykuł podejmuje także kwestię metodyczną związaną z graficzną prezentacją zmiennych mierzonych na słabych skalach pomiaru, które często występują w badaniach sondażowych. Wizualizacja danych zyskuje coraz większe znaczenie w dobie istnienia coraz to większych zasobów informacji i staje się także ważnym elementem prezentacji wyników badań. Jak wskazują Du Toit, Steyn i Stumpf, istnieją trzy zasadnicze sposoby przekazywania informacji statystycznej: słowa, tabele i grafika, które wzajemnie się uzupełniają ${ }^{10}$. O ile wykresy ilustrujące zależności dla zmiennych ze skal metrycznych stosowane są dosyć często, o tyle techniki wizualizacji powiązań danych niemetrycznych używane są rzadziej. Ponieważ podstawą przeprowadzonych badań były analizy tabel kontyngencji (krzyżowych), przedstawiono kilka technik ich graficznej prezentacji, które pozwalają zilustrować relacje istniejące pomiędzy dwiema zmiennymi dwukategorialnymi. Warto nadmienić, że wszystkie zaprezentowane metody są dostępne w ramach programu $\mathrm{R}$ na licencji GNU (wolnego i otwartego oprogramowania), co niewątpliwie może przyczynić się do ich szerszego stosowania do przedstawiania rezultatów badań.

${ }^{7}$ Tamże, s. 114.

${ }^{8}$ E. Dolny, Determinanty kontynuowania pracy $i$ aktywizacji zawodowej $w$ starszym wieku, [w:] Determinanty aktywności zawodowej osób starszych, Dom Organizatora, Torun 2009, s. 123-134

${ }^{9}$ Tamże, s. 134.

${ }^{10}$ S.H.C. Du Toit, A.G.W. Steyn, R.H. Stumpf, Graphical Exploratory Data Analysis, Springer-Verlag New York, Inc., 1986, s. 1. 


\section{2. Źródła danych i zastosowane metody badawcze}

W części analitycznej opracowania wykorzystano dane pochodzące z badań sondażowych zrealizowanych w ramach drugiej i trzeciej rundy projektu SHARE, które miały miejsce odpowiednio w latach 2006-2007 oraz 2010-2012 ${ }^{11}$. Wybór rund był uwarunkowany stosowaniem w nich analogicznych pytań dających porównywalny materiał badawczy. Uzyskane informacje pozwoliły zestawić odsetek osób w Polsce deklarujących chęć jak najszybszego wycofania się z rynku pracy z poglądami na ten temat osób z pozostałych krajów. Do sprawdzenia hipotezy o istnieniu związku pomiędzy postrzeganiem warunków pracy a skłonnością do szybkiej rezygnacji z aktywności zawodowej wykorzystano odpowiedzi odzwierciedlające postawy respondentów co do stwierdzeń dotyczących pracy ${ }^{12}$ :

- wymóg dużego wysiłku fizycznego,

- bycie pod presją czasu,

- mała swoboda w zakresie sposobu wykonywania obowiązków,

- możliwość zdobywania nowych umiejętności,

- otrzymywanie wsparcia w trudnych sytuacjach,

- spotykanie się z uznaniem,

- otrzymywanie adekwatnego wynagrodzenia,

- bycie zadowolonym z pracy,

- niewielkie szanse na awans,

- mała pewność zatrudnienia.

${ }^{11}$ Dane wykorzystane w artykule pochodzą z rundy 4 badania SHARE (release 1.1.1 z 28.03.2013 r.). Utworzenie zbioru danych SHARE zostało sfinansowane w głównej mierze ze środków Komisji Europejskiej w ramach 5. Programu Ramowego (projekt QLK6-CT-2001-00360 w programie Quality of Life), w ramach 6. Programu Ramowego (projekty: SHARE-I3, RII-CT-2006-062193, COMPARE, CIT5-CT-2005-028857, i SHARELIFE, CIT4-CT-2006-028812) orazw ramach 7. Programu Ramowego (SHARE-PREP, $\mathrm{N}^{\circ}$ 211909, SHARE-LEAP, N²27822 i SHARE M4, N²61982). Dodatkowe finansowanie projektu pochodziło z amerykańskiego National Institute on Aging (U01 AG09740-13S2, P01 AG005842, P01 AG08291, P30 AG12815, R21 AG025169, Y1-AG-4553-01, IAG BSR06-11 and OGHA 04-064), niemieckiego Ministerstwa Edukacji i Badań, polskiego Instytutu Badań Edukacyjnych oraz innych krajowych źródeł (pełna lista fundatorów znajduje się na stronie www.share-project.org).

[This paper uses data from SHARE wave 4 release 1.1.1, as of March 28th 2013. The SHARE data collection has been primarily funded by the European Commission through the 5th Framework Programme (project QLK6-CT-2001-00360 in the thematic programme Quality of Life), through the 6th Framework Programme (projects SHARE-I3, RII-CT-2006-062193, COMPARE, CIT5CT-2005-028857, and SHARELIFE, CIT4-CT-2006-028812) and through the 7th Framework Programme (SHARE-PREP, N 211909, SHARE-LEAP, N 227822 and SHARE M4, N 261982). Additional funding from the U.S. National Institute on Aging (U01 AG09740-13S2, P01 AG005842, P01 AG08291, P30 AG12815, R21 AG025169, Y1-AG-4553-01, IAG BSR06-11 and OGHA 04064) and the German Ministry of Education and Research as well as from various national sources is gratefully acknowledged (see www.share-project.org for a full list of funding institutions)].

$12 \mathrm{http} / / /$ www.share-project.org/fileadmin/pdf_questionnaire_wave_4/SHARE_PL_wave4_main questionnaire.pdf, s.52-53, [dostęp 2014-01-31] 
Wszystkie wymienione stwierdzenia ankietowani oceniali w czterostopniowej skali: zdecydowanie się zgadzam, zgadzam się, nie zgadzam się, zdecydowanie się nie zgadzam. W celu analizy dokonano transformacji odpowiedzi na zmienne dychotomiczne reprezentujące bądź akceptację danego sformułowania, bądź jej brak. Opinie dotyczące różnych przejawów wykonywanej pracy zostały skonfrontowane z odpowiedziami na następujące pytanie: myślac o swojej obecnej pracy, czy [chciałby Pan/chciałaby Pani] odejść z tej pracy na emeryturę tak szybko, jak to możliwe? ${ }^{13}$, na które odpowiedź sformułowano w sposób binarny (tak, nie).

Dane odnośnie do chęci rezygnacji z aktywności zawodowej i opinii na temat pracy zebrane w trakcie badania SHARE pozwalają zbadać, czy istnieje związek pomiędzy skłonnością do zaprzestania pracy a oceną różnych jej aspektów. Opinie respondentów były wyrażane na skalach słabych, stąd punktem wyjścia do ich analizy była konstrukcja dwuwymiarowych tabel krzyżowych (kontyngencji), w których zawarte zostały zmienne binarne reprezentujące zgodę ankietowanych, bądź jej brak, ze stwierdzeniami zawartymi w kwestionariuszu. W celu zweryfikowania hipotezy o niezależności cech zastosowano test chi-kwadrat. Wysokie wartości statystyki tego testu sugerują odrzucenie hipotezy zerowej na rzecz alternatywnej, pozwalając wnioskować o istnieniu zależności. Rezultaty testu warto wesprzeć badaniem siły związku pomiędzy rozpatrywanymi zmiennymi. W literaturze znaleźć można różne propozycje miar powiązania dwóch zmiennych jakościowych, których przegląd przedstawiono m.in. w pracach: Bishop i in. ${ }^{14}$, Brzezińskiego (red.) ${ }^{15}$, Liebetrau ${ }^{16}$. W niniejszym opracowaniu zastosowano dwie miary o różnorakim charakterze. Po pierwsze, współczynnik phi Yule'a ${ }^{17}$ będący miarą symetryczną, czyli niewyróżniającą zmiennej zależnej i niezależnej, stosowaną dla zmiennych dwukategorialnych. Po drugie, współczynnik niepewności (entropii) ${ }^{18}$ jako miarę kierunkową, do obliczenia której niezbędne jest określenie charakteru zmiennych. Podstawowe własności zastosowanych miar zawarto w tab. 1.

Omówione powyżej współczynniki w syntetyczny sposób opisują zależność pomiędzy dwiema zmiennymi jakościowymi, dla których można utworzyć tablicę krzyżową o wymiarach $2 \times 2$. W celu lepszego wglądu w charakter relacji pomiędzy cechami warto sięgnąć po techniki wizualizacji tabel kontyngencji ${ }^{19}$,

${ }^{13}$ Tamże, s. 53

${ }^{14}$ Y.M. Bishop, S.E. Fienberg, P.W. Holland, Discrete Multivariate Analysis: Theory and Practice, Springer 2007, s. 376-392.

${ }^{15}$ J. Brzeziński (red.), Metodologia badań psychologicznych. Wybór tekstów, Wydawnictwo Naukowe PWN, Warszawa 2004, s. 479-496.

${ }^{16}$ A.M. Liebetrau, Measures of Association, Sage University Paper series on Quantitative Application in the Social Sciences, Sage Pubns., Beverly Hills and London 1983.

${ }^{17}$ Zob. np. Brzeziński, wyd. cyt., s. 493.

${ }^{18}$ Zob. W.H. Press, Numerical Recipes 3rd Edition: The Art of Scientific Computing, Cambridge University Press, 2007, s. 761.

${ }^{19}$ Zob. M. Friendly, Visualizing Categorical Data, SAS Institute, Cary NC 2000. 
Tabela 1. Zestawienie zastosowanych miar siły związku zmiennych

\begin{tabular}{|l|l|l|l|}
\hline \multicolumn{1}{|c|}{ Miara } & \multicolumn{1}{|c|}{ Charakter } & $\begin{array}{c}\text { Zakres } \\
\text { wartości }\end{array}$ & \multicolumn{1}{c|}{ Interpretacja } \\
\hline $\begin{array}{l}\text { Współczynnik } \\
\text { phi Yule'a }\end{array}$ & symetryczna & $<-1,1>$ & $\begin{array}{l}\text { wartość bezwzględna odzwierciedla siłę związku } \\
\text { dwóch zmiennych niemetrycznych; znak współ- } \\
\text { czynnika wskazuje na kierunek zależności (w przy- } \\
\text { padkach, kiedy ma sens rozpatrywanie kierunku } \\
\text { zależności) }\end{array}$ \\
\hline $\begin{array}{l}\text { Współczynnik } \\
\text { niepewności }\end{array}$ & $\begin{array}{l}\text { kierunkowa } \\
\text { (asymetryczna) }\end{array}$ & $<0,1>$ & $\begin{array}{l}\text { zakres zmniejszenia niepewności (błędu) w przewi- } \\
\text { dywaniu zmiennej zależnej na podstawie znajomości } \\
\text { wartości zmiennej niezależnej; im wartości bliższe } \\
\text { 1, tym wiedza o zmiennej niezależnej w większym } \\
\text { stopniu pozwala przewidywać zmienną zależną }\end{array}$ \\
\hline
\end{tabular}

Źródło: opracowanie własne.

wśród których do mało złożonych, a zarazem informatywnych zaliczyć można wykres bąbelkowy (balloon plot), wykres czteropolowy (fourfold display) oraz wykres piętrowy (doubledecker plot). Zestawienie tego rodzaju wizualizacji dla przykładowej tabeli kontyngencji przedstawiono na rys. 2 .

Tabela kontyngencji:

Wykres bąbelkowy:

\begin{tabular}{|c|c|c|}
\hline \multirow{2}{*}{ Cecha A } & \multicolumn{2}{|c|}{ Cecha B } \\
\cline { 2 - 3 } & Tak & Nie \\
\hline Tak & 50 & 10 \\
\hline Nie & 21 & 30 \\
\hline
\end{tabular}

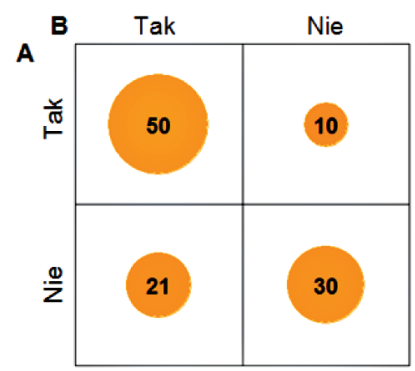

Wykres czteropolowy:

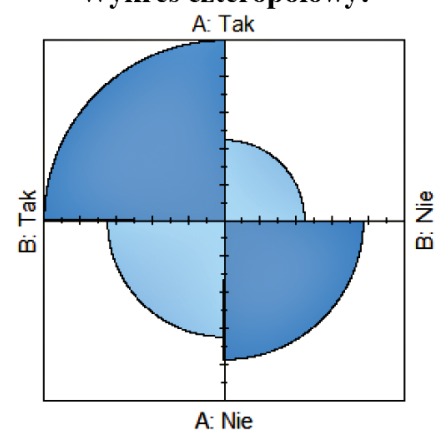

Wykres piętrowy:

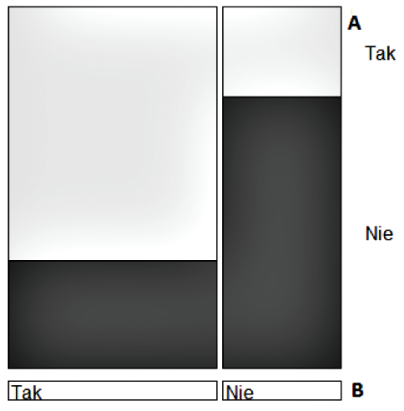

Rys. 2. Przykładowa tabela kontyngencji i różne metody jej wizualizacji

Źródło: opracowanie własne z wykorzystaniem programu R. 
Na wykresie bąbelkowym elementy tabeli krzyżowej reprezentowane są za pomocą kół o polach proporcjonalnych do liczebności, czyli wyrażają ich względną wielkość. Wykres piętrowy ${ }^{20}$ składa się z kolumn o szerokości odzwierciedlającej liczebności poszczególnych kategorii jednej cechy, podczas gdy cieniowanie (lub zróżnicowana kolorystyka) odtwarza rozkład drugiej zmiennej. Z kolei na wykresie czteropolowym każda z komórek tabeli reprezentowana jest przez ćwiartkę koła, której powierzchnia jest proporcjonalna do liczebności, dzięki czemu możliwa jest identyfikacja istnienia związku cech - ma to miejsce, gdy pola ćwiartek położonych wzdłuż jednej przekątnej znacznie się różnią od pól ćwiartek położonych w kierunku przeciwnym, co jest uwidocznione za pomocą kolorów lub cieniowania ${ }^{21}$. Wymienione wizualizacje stanowią czytelną i ciekawą formę prezentacji tabel kontyngencji. W celu ilustracji zachodzących prawidłowości w dalszej części artykułu wykorzystano wykresy czteropolowe, ze względu na fakt, że oprócz interesującej formy wnoszą także informacje o istnieniu bądź braku związku pomiędzy cechami.

\section{Analiza związków pomiędzy cechami pracy a skłonnością do przechodzenia na emeryturę}

Zanim zostanie zaprezentowana szczegółowa analiza danych dotyczących Polski, warto przyjrzeć się zapatrywaniom osób 50+ w szerszym, europejskim kontekście. Interesująco wypada zestawienie odsetka respondentów uczestniczących w rynku pracy z odsetkiem osób chętnych do jego opuszczenia. Na rysunku 3 zestawiono procent respondentów wykonujących pracę zawodową z odsetkiem osób skłonnych do przejścia na emeryturę tak szybko, jak to możliwe. Interesujące jest, że pomiędzy tymi dwiema zmiennymi można zauważyć ujemną zależność. W krajach, w których procent osób pracujących w wieku 50+ jest najwyższy, chęć do dezaktywizacji zawodowej wśród nich jest najniższa, przy czym ta prawidłowość najwyraźniej uwidacznia się w przypadku Danii, Szwajcarii, Szwecji i Estonii. Polska znajduje się na drugim „biegunie” wykresu z bardzo niską frakcją respondentów pracujących zawodowo i jednocześnie jednym z najwyższych odsetków ankietowanych skłonnych do rezygnacji z pracy na rzecz emerytury. Takie umiejscowienie Polski na tle pozostałych krajów było podobne w obydwóch rundach badania.

Korzystając $\mathrm{z}$ danych zgromadzonych w ramach projektu SHARE, obliczono miary związku pomiędzy zmienną reprezentującą chęć do jak najszybszego przejścia na emeryturę a zmiennymi odzwierciedlającymi poglądy na temat różnych aspektów pracy. Rezultaty otrzymane na podstawie danych zebranych w trakcie drugiej rundy

${ }^{20}$ Zob. np. H. Hofmann, A.P. Siebes, Wilhelm A.F., Visualizing Association Rules with Interactive Mosaic Plots [Extended Abstract], http://www.researchgate.net/publication/221653528_Visualizing association_rules_with_interactive_mosaic_plots/file/9c96052a0a237b5438.pdf [dostęp 2013-01-31].

${ }^{21}$ M. Friendly, wyd. cyt., s. 74-75. 
badania (2006/2007) zaprezentowano w tab. 2, przy czym uszeregowano je w kolejności od najsilniejszego do najsłabszego stopnia powiązania cech. Graficzną ilustrację analizowanych zależności przedstawiono na rys. 4 .

Runda 2

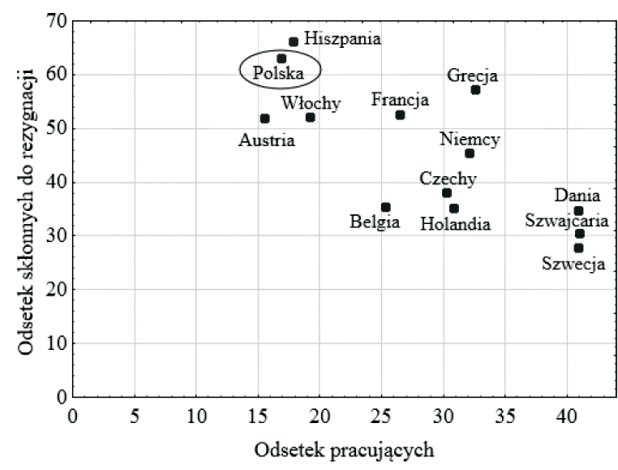

Runda 4

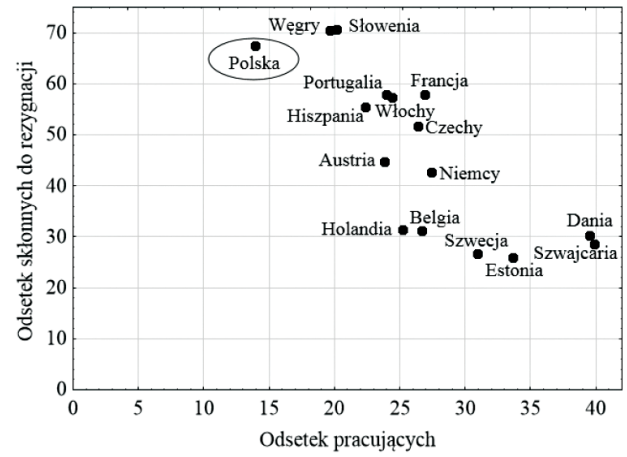

Rys.3. Relacja pomiędzy odsetkiem pracujących respondentów a odsetkiem ankietowanych deklarujących chęć rezygnacji z pracy na rzecz emerytury tak szybko, jak to możliwe

Źródło: opracowanie własne na podstawie danych SHARE, runda 2 i 4.

Tabela 2. Wartości statystyki chi-kwadrat oraz miary siły związku pomiędzy zmiennymi reprezentującymi różne aspekty pracy a skłonnością do przechodzenia na emeryturę, druga runda SHARE $(2006 / 2007)$

\begin{tabular}{|l|c|c|c|c|}
\hline \multicolumn{1}{|c|}{ Stwierdzenia dotyczące pracy } & $\begin{array}{c}\text { Statystyka } \\
\text { chi-kwadrat }\end{array}$ & $\begin{array}{c}\text { Miara } \\
\text { phi }\end{array}$ & $\begin{array}{c}\text { Współczynnik } \\
\text { niepewności }\end{array}$ & $\mathrm{N}$ \\
\hline Odpowiednie wynagrodzenie & $28,877^{* *}$ & $-0,264^{* *}$ & $0,052^{* *}$ & 413 \\
\hline Możliwość zdobywania nowych umiejętności & $17,583^{* *}$ & $-0,206^{* *}$ & $0,032^{* *}$ & 413 \\
\hline Ogólne zadowolenie z pracy & $15,209^{* *}$ & $-0,192^{* *}$ & $0,033^{* *}$ & 413 \\
\hline Wsparcie w trudnych sytuacjach & $13,173^{* *}$ & $-0,180^{* *}$ & $0,025^{* *}$ & 408 \\
\hline Należyte uznanie & $10,482^{* *}$ & $-0,161^{* *}$ & $0,021^{* *}$ & 405 \\
\hline Niewielkie szanse awansu & $7,168^{* *}$ & $0,132^{* *}$ & $0,013^{* *}$ & 411 \\
\hline Wymóg dużego wysiłku fizycznego & $5,863^{*}$ & $0,119^{*}$ & $0,011^{*}$ & 413 \\
\hline Mała pewność zatrudnienia & 2,871 & 0,084 & 0,005 & 409 \\
\hline Ciągła presja czasowa & 0,758 & 0,043 & 0,001 & 412 \\
\hline Mała swoboda w sposobie wykonywania pracy & 0,624 & 0,039 & 0,001 & 413 \\
\hline
\end{tabular}

** istotność (przybliżona) przy $p=0,01 ;{ }^{*}$ istotność (przybliżona) przy $p=0,05$

Źródło: obliczenia własne na podstawie danych SHARE, runda 2. 

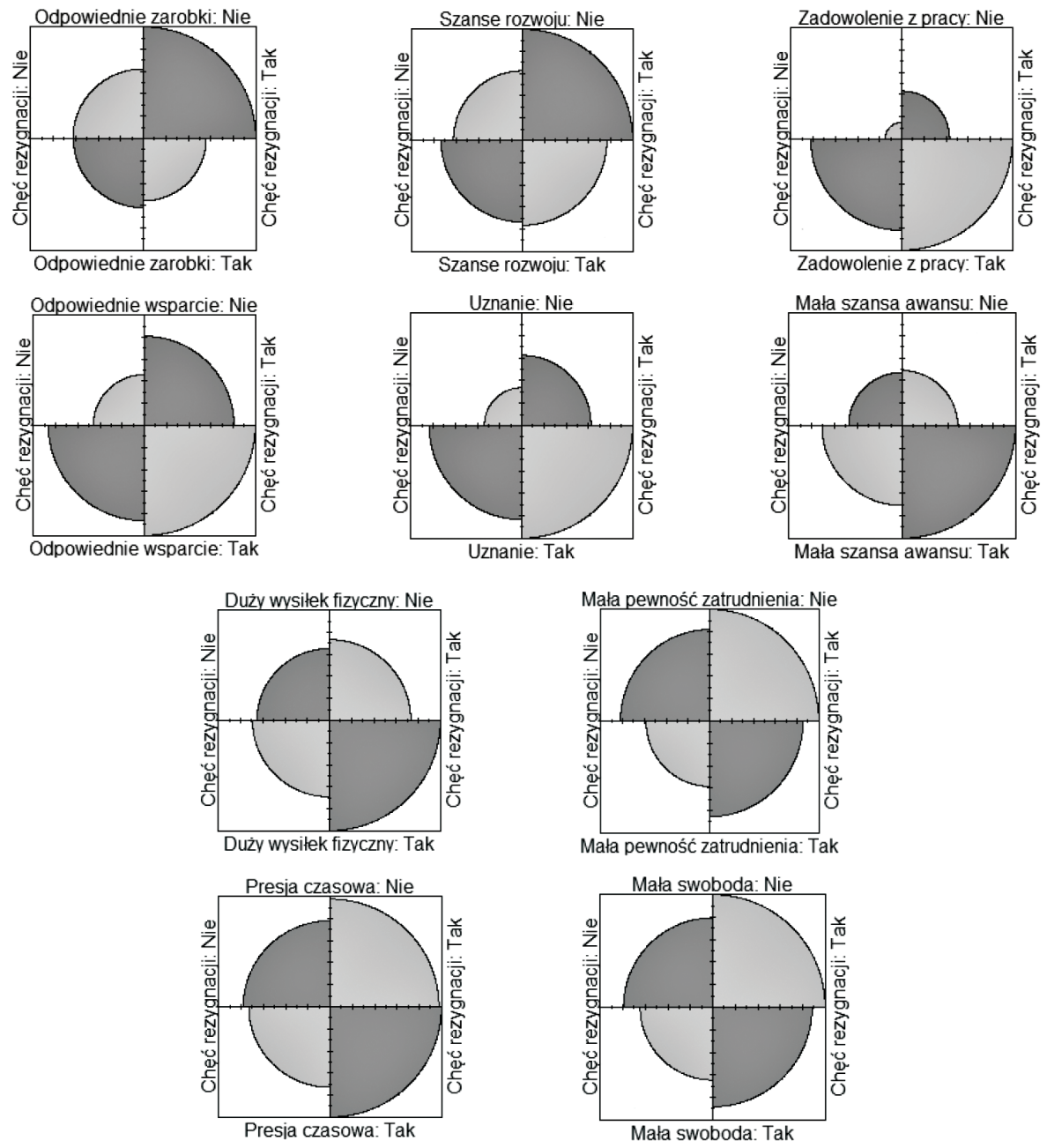

Rys. 4. Wykresy czteropolowe przedstawiające graficznie tabele krzyżowe dotyczące różnych aspektów pracy i skłonności do rezygnacji z zatrudnienia

Źródło: opracowanie własne na podstawie danych SHARE, runda 2.

Na dziesięć analizowanych stwierdzeń dotyczących pracy siedem wykazało statystycznie istotny związek z chęcią wyjścia z rynku pracy. Brak tego rodzaju zależności stwierdzono w odniesieniu do trzech czynników: niewielkiej swobody w sposobie wykonywania obowiązków służbowych, istnienia presji czasu oraz braku pewności zatrudnienia. Wśród istotnych aspektów dwa odznaczały się zależnością dodatnią z chęcią przejścia na emeryturę tak szybko, jak to możliwe - praca obciążająca fizycznie oraz małe szanse awansu. Pozostałe stwierdzenia były powiązane ujemnie, przy czym najsilniejsza zależność wystąpiła w przypadku czynnika finansowego. Osoby, 
które uznawały, że nie osiągają odpowiednich zarobków, bardziej zdecydowanie deklarowały, że chciałyby prędko zrezygnować z pracy zawodowej. Ta zależność jest doskonale widoczna na wykresie czteropolowym (rys. 4), na którym ćwiartka koła reprezentująca kombinację odpowiedzi „brak odpowiednich zarobków - chęć rezygnacji z pracy" jest znacznie większa niż pozostałe. Podobna sytuacja zarysowała się w kontekście możliwości zdobywania nowych umiejętności. Brakowi szans na rozwój zawodowy często towarzyszy inklinacja do przejścia na emeryturę. Można również zauważyć, że mniejsza skłonność do dezaktywizacji zawodowej uwidacznia się u osób, które spotykają się z należytym uznaniem i mogą liczyć na wsparcie w problemowych sytuacjach. Ogólne zadowolenie z pracy także predestynuje do jej utrzymywania. Mimo że wymienione zależności są statystycznie istotne, należy zauważyć, że siła związku nie jest znaczna. Co więcej, wartości współczynnika niepewności wskazują, że poszczególne cechy pracy są raczej słabym predyktorem skłonności respondentów do pozostawania aktywnym zawodowo. Warto natomiast nadmienić, że wykresy czteropolowe pozwalają dodatkowo poczynić ciekawe spostrzeżenia. Polacy w wieku 50+ są raczej zadowoleni z wykonywanej pracy, choć raczej nie widzą szans na rozwój zawodowy i awans oraz przeważnie otrzymują nieadekwatne wynagrodzenie. Z drugiej strony, większość respondentów spotyka się $\mathrm{w}$ pracy $\mathrm{z}$ uznaniem i otrzymuje niezbędną pomoc $\mathrm{w}$ razie wystąpienia trudności.

Tabela 3. Wartości statystyki chi-kwadrat oraz miary siły związku zmiennych reprezentujących różne aspekty pracy i skłonności do wychodzenia z rynku pracy, czwarta runda SHARE (2010-2012)

\begin{tabular}{|l|c|c|c|c|}
\hline \multicolumn{1}{|c|}{ Stwierdzenia dotyczące pracy } & $\begin{array}{c}\text { Statystyka } \\
\text { chi-kwadrat }\end{array}$ & $\begin{array}{c}\text { Miara } \\
\text { phi }\end{array}$ & $\begin{array}{c}\text { Współczynnik } \\
\text { niepewności }\end{array}$ & $\mathrm{N}$ \\
\hline Należyte uznanie & $13,722^{* *}$ & $-0,248^{* *}$ & $0,052^{* *}$ & 223 \\
\hline $\begin{array}{l}\text { Możliwość zdobywania nowych } \\
\text { umiejętności }\end{array}$ & $9,242^{* *}$ & $-0,204^{* *}$ & $0,032^{* *}$ & 223 \\
\hline Wymóg dużego wysiłku fizycznego & $8,188^{* *}$ & $0,192^{* *}$ & $0,028^{* *}$ & 223 \\
\hline Mała pewność zatrudnienia & $7,887^{* *}$ & $0,188^{* *}$ & $0,028^{* *}$ & 223 \\
\hline Odpowiednie wynagrodzenie & $7,589^{* *}$ & $-0,184^{* *}$ & $0,026^{* *}$ & 223 \\
\hline Wsparcie w trudnych sytuacjach & $6,186^{*}$ & $-0,167^{*}$ & $0,022^{*}$ & 223 \\
\hline Ogólne zadowolenie z pracy & $6,027^{*}$ & $-0,164^{*}$ & $0,025^{* *}$ & 223 \\
\hline $\begin{array}{l}\text { Mała swoboda w sposobie } \\
\text { wykonywania pracy }\end{array}$ & 1,217 & 0,074 & 0,004 & 223 \\
\hline Niewielkie szanse awansu & 0,610 & 0,052 & 0,002 & 223 \\
\hline Ciągła presja czasowa & 0,196 & 0,030 & 0,001 & 223 \\
\hline
\end{tabular}

** istotność (przybliżona) przy $p=0,01 ;{ }^{*}$ istotność (przybliżona) przy $p=0,05$

Źródło: obliczenia własne na podstawie danych SHARE, runda 4. 
Analogiczną analizę przeprowadzono dla danych pochodzących z czwartej rundy badania SHARE (2010-2012). Wartości statystyki chi-kwadrat oraz mierniki siły związku obliczone na podstawie danych zgromadzonych podczas czwartej rundy badania (2010-2012) przedstawiono $\mathrm{w}$ tab. 3, porządkując je zgodnie ze stopniem powiązania cech. Wizualizacje rozpatrywanych zależności zawiera rys. 5 .
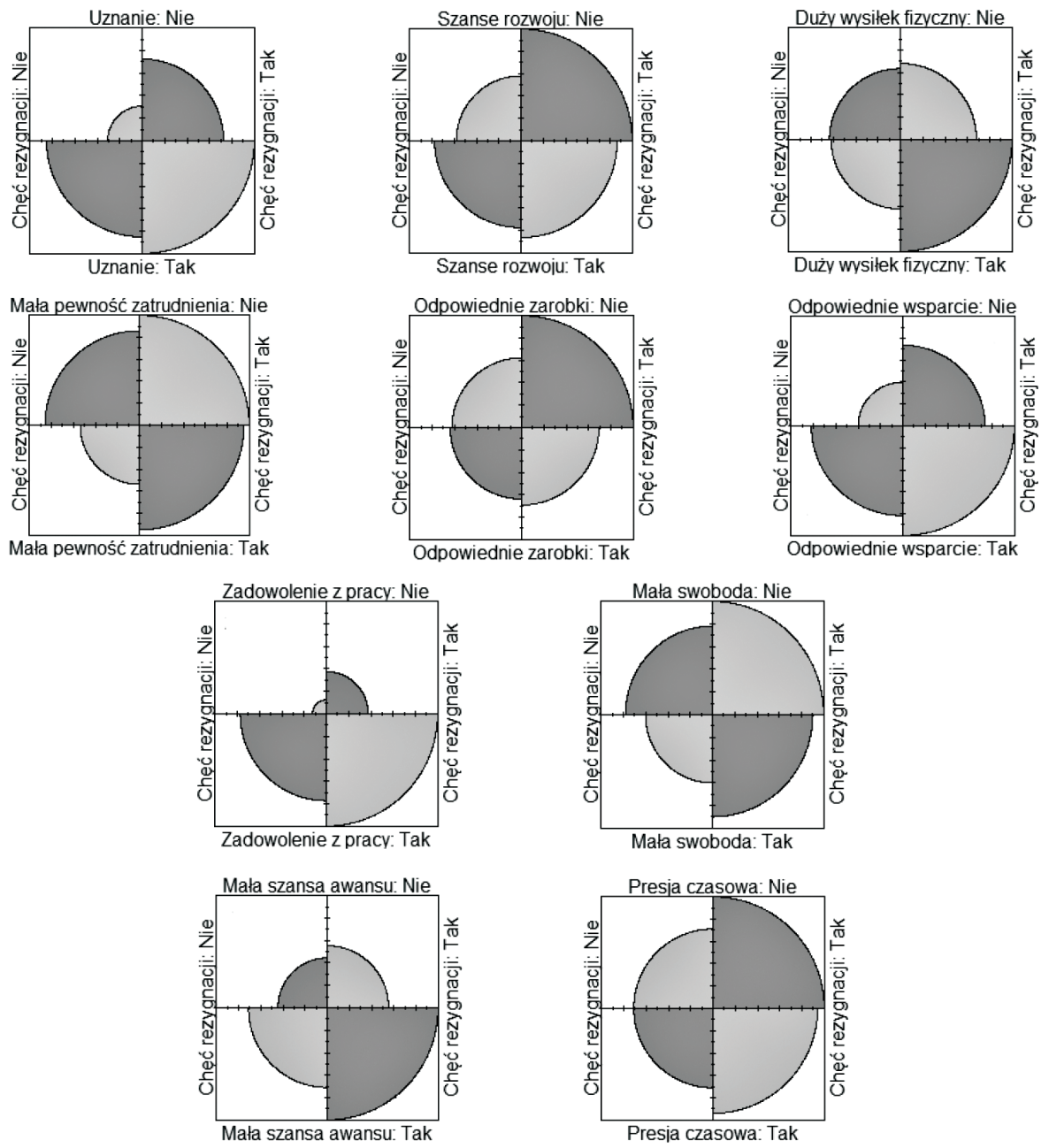

Rys. 5. Wykresy czteropolowe przedstawiające graficznie tabele krzyżowe dotyczące różnych aspektów pracy i skłonności do rezygnacji z zatrudnienia

Źródło: opracowanie własne na podstawie danych SHARE, runda 4.

W najnowszym badaniu wśród analizowanych czynników trzy okazały się statystycznie nieistotne: presja czasu, małe szanse awansu oraz niewielka swoboda w sposobie wykonywania pracy. Istotną dodatnią zależność odnotowano dla takich 
aspektów, jak: wymóg dużego wysiłku fizycznego oraz mała pewność zatrudnienia, natomiast pozostałe istotne właściwości pracy wykazały ujemny związek z deklarowaną skłonnością do ukończenia aktywności zawodowej. Najsilniejsze powiązanie $\mathrm{z}$ chęcią kontynuowania pracy wystąpiło w przypadku otrzymywania stosownego uznania oraz istnienia właściwych warunków do zdobywania nowych umiejętności. Do utrzymywania aktywności zawodowej skłaniają również: odpowiednie wynagrodzenie, wsparcie w trudnych sytuacjach oraz odczuwane zadowolenie z pracy. Jednakże miary phi Yule'a, wprawdzie istotne statystycznie, kształtują się co do modułu poniżej wartości 0,25 , co wskazuje na słabą zależność analizowanych cech. Do podobnego wniosku skłaniają wartości współczynników niepewności, sygnalizujące, że przewidywanie skłonności do dezaktywizacji zawodowej na podstawie informacji o kształtowaniu się zmiennych odzwierciedlających poglądy na temat wykonywanej pracy tylko w niewielkim stopniu redukuje potencjalne błędy we wnioskowaniu.

Rozkłady liczebności w tabelach kontyngencji, które zostały zilustrowane za pomocą wykresów czteropolowych (rys. 5), pozwalają stwierdzić, że wśród respondentów, podobnie jak w badaniu w ramach rundy 2, przeważały osoby zadowolone z pracy, spotykające się w niej z uznaniem i otrzymujące wsparcie, ale słabo oceniające szanse rozwoju, możliwości awansu i adekwatność wynagrodzenia.

\section{Podsumowanie}

Rezultaty otrzymane na podstawie dwóch rund badania nie są identyczne. Wcześniejszy sondaż wskazywał, że chęć jak najszybszego przejścia na emeryturę nie jest powiązana z oceną pewności zatrudnienia, w nowszym ten czynnik okazał się istotny. Odwrotną prawidłowość odnotowano dla opinii na temat możliwości awansu. Siła związku analizowanych aspektów pracy ze skłonnością do dezaktywizacji zawodowej była różna w poszczególnych rundach. O ile w rundzie 2 najważniejszą determinantą utrzymywania zatrudnienia było odpowiednie wynagrodzenie, o tyle w rundzie 4 na czele listy znalazło się należyte uznanie za wykonywaną pracę. Warto podkreślić, że w obu sondażach bardzo wysoko uplasowała się możliwość zdobywania nowych umiejętności, co wskazuje na pewne trwałe przekonania o znaczeniu perspektyw na rozwój zawodowy w kontekście zachowania wykonywanej pracy. W obu badaniach jako nieistotne czynniki zidentyfikowane zostały: mała swoboda w sposobie wykonywania pracy oraz presja czasu.

Przeprowadzone badanie wykazało, że istnieje związek pomiędzy oceną wybranych aspektów pracy a skłonnością do przechodzenia na emeryturę. Okazuje się jednak, że siła tego związku nie jest zbyt duża. Posiadanie wiedzy o przeświadczeniach osób starszych o wykonywanej pracy nie podnosi znacznie jakości predykcji zachowań związanych z dezaktywizacją zawodową. Wydaje się, że na tego typu decyzje decydujący wpływ mogą mieć raczej inne czynniki, niezwiązane z oceną właściwości aktualnej pracy. 


\section{Literatura}

Bishop Y.M., Fienberg S.E., Holland P.W., Discrete Multivariate Analysis: Theory and Practice, Springer, New York 2007.

Brzeziński J. (red.), Metodologia badań psychologicznych. Wybór tekstów, Wydawnictwo Naukowe PWN, Warszawa 2004.

Dolny E., Determinanty kontynuowania pracy i aktywizacji zawodowej w starszym wieku, [w:] Determinanty aktywności zawodowej osób starszych, Dom Organizatora, Torun 2009.

Du Toit S.H.C., Steyn A.G.W., Stumpf R.H., Graphical Exploratory Data Analysis, Springer-Verlag New York, Inc., 1986.

Friendly M., Visualizing Categorical Data, SAS Institute, Cary NC 2000.

Hofmann H., Siebes A.P., Wilhelm A.F., Visualizing Association Rules with Interactive Mosaic Plots [Extended Abstract], http://www.researchgate.net/publication/221653528_Visualizing_association_rules_with_interactive_mosaic_plots/file/9c96052a0a237b5438.pdf [dostęp 2013-01-31].

Kabaj M., Aktywność zawodowa i zatrudnienie ludzi starszych, [w:] Polska w obliczu starzenia się społeczeństwa, PAN, Komitet Prognoz „Polska 2000 Plus”, Warszawa 2008.

Liebetrau A.M., Measures of Association, Sage University Paper series on Quantitative Application in the Social Sciences, Sage Pubns., Beverly Hills and London 1983.

Press W.H., Numerical Recipes 3rd Edition: The Art of Scientific Computing, Cambridge University Press, 2007.

\section{WORK CHARACTERISTICS AND THE TENDENCY OF POLES AGED 50+ TO RESIGN FROM WORK}

Summary: This paper considers relations between the assessment of work characteristics and the tendency of Poles aged 50+ to transit from employment into retirement. Using the results from two surveys carried out under the SHARE project, the hypothesis was verified that there are associations between the evaluation of current work features and the inclination to retire as soon as possible. The direction and strength of the relationships between the opinions expressed by respondents were evaluated by measures adequate for categorical variables. The analysis was supported by visualizations of fourfold contingency tables. The study indicates that there are statistically significant relations between the perception of some work characteristics and the tendency of Poles to quit the labor market, but the strength of these associations is rather weak. The obtained result suggests that the substantial determinants of willingness to retirement are probably different in nature.

Keywords: work features, transition from work to retirement, persons $50+$. 